UNTAG Law Review (ULREV)

Volume 1, Issue 2, Nov 2017, PP 51-59

ISSN 2549-4910 (online) \& ISSN 2579-5279 (print)

http://jurnal.untagsmg.ac.id/indeks.php/ulrev/indeks

www.fakhukum.untagsmg.ac.id

\title{
DYNAMICS OF CONSTITUTION IN 1945 AMENDMENTS \\ AS A CONSTITUTIONAL IN INDONESIA
}

\author{
Asri Agustiwi
}

Surakarta University

\begin{abstract}
The constitution is often equated with the Constitution as the basic law is written. However, the Constitution of having understanding wider. The Constitution does not only include a written rule that constitution, but the unwritten rule, the basic rules are raised and maintained in the practice of statecraft or called by convention. The Constitution is the constitutional system in the form of written and unwritten rules set out together to govern a country. Where the nature and function of the constitution is there limitation of government power so that the implementation of power is not arbitrary. Thus, the rights of citizens are expected to be protected. 1945 was passed by the state constitution PPKI as Indonesia on August 18, 1945. In practice, the 1945 Constitution of Indonesia has been transformed into constitutional RIS (December 27th 1945-August 17, 1950), later transformed into a Provisional Constitution of 1950 (August 17th 1950s July 5th, 1959), until it became 1945 again but with amendments in 1999, 2000, 2001 and 2002. An amendment to the 1945 Constitution because their demands strong 1945 changes of society. People feel that the charge 1945 times many are not appropriate.
\end{abstract}

Keywords: Dynamics, Constitution, Constitutional

\section{INTRODUCTION}

The Constitution is the basic law of a country. Every country must have a constitution. Because of the absence of the state constitution not be formed. As the basic law of the country, the Constitution of containing the rules and provisions on fundamental things in the life of a country. So all the practices in the administration of the state should be based on the constitution and must not conflict with the constitution.

As well as the practice of holding state in Indonesia also based on the constitution. It can be observed in the 1945 opening sentence of the 4th paragraph is read: "... then than it is to establish a State Government of Indonesia to protect the entire Indonesian nation and the entire homeland of Indonesia and to promote the general welfare, educate life of the nation, and participate in implementing world order based on freedom, lasting peace and social justice, then drafted Indonesia's National independence in an Act of the State of Indonesia. "From this statement it is clear that Indonesia has a constitution as the constitution of the basic law is written.

In general, the constitution is often equated with the Constitution as the basic law is written. However, the Constitution of having understanding wider. The Constitution does not only 
include a written rule that constitution, but the unwritten rule, the basic rules are raised and maintained in the practice of statecraft or called by convention.

As we know that the presence of the constitution or basic law is a necessary condition for a country. No country in the world that does not have a constitution or basic law. In its history, Indonesia has prevailed in three kinds of constitutions in four periods: 1945 (1945-1949), the Constitution RIS (1949-1950), the Provisional Constitution (1950-1959), and back again to 1945 (1959- present ). As the basic law of the country of Indonesia, the 1945 certainly has the status, role and function very urgent. When viewed from the history, 1945 is the result of the political struggle of the Indonesian nation and at the same time it is the view of the national figures (founding fathers) to be realized both for the present, and for the foreseeable future. Thus, 1945 should serve as a cornerstone in the implementation of the Government of the Republic of Indonesia.

In practice, the 1945 experience that follows the dynamics of change in the country's political system in Indonesia. 1945 experienced four times the amendment process carried out by the Assembly, namely 1999, 2000, 2001, and 2002. These changes include almost the entire substance of the 1945, except for the opening and the principles of a state that has been agreed to by default. This amendment process is deemed necessary, given the changes in people's lives, both internally and externally. Thus, the constitution as the foundation of life of the state must constantly adapt to developments in society. Do not let the constitution is outdated and no longer able to function as the state. Therefore, the amendment is expected to bring progress in the constitutional life in Indonesia.

Based on the above background, a problem can be formulated as follows:

1. How do the dynamics of the implementation of the 1945 Constitution of Indonesia?

2. Why do an amendment to the 1945 Constitution?

\section{DISCUSSION}

\section{Dynamics Implementation of the Constitution of the State 1945 As Indonesia.}

\section{a. Understanding Basic Concepts of the Constitution}

Constitutional term comes from French(constituer) which means form. Use of the term constitutional question is the establishment of a state or prepare and declare the rules of a country (Srijanti et al, 2008). The Constitution can be equated with the basic law or constitution. The constitution is the basic law constitutional term written. In Dutch language known by the term "Ground wet" which is translated as the basic law. In Indonesian, wet translated as law, and Ground, which is land. In countries that use English as the national language, used the term Constitution which translates into Indonesian be constitutional. Understanding the constitution in practice have a broader understanding of the constitution.

In political science, Constitution is a broader, ie the entirety of regulations both written and unwritten set binding ways how things are maintained in the public administration. In German constitutional term is also known as the Grundgesetz, which also means the constitution. Grund is defined as basic and gesetz interpreted the law. While the constitution says in big Indonesian dictionary is defined as all the conditions and rules regarding the constitution and also interpreted as the basic law of a country.

The term constitution by Chairul Anwar is fundamental laws about the of the state government and fundamental values. Meanwhile, according to Sri Soemantri, constitution means a script 
that makes a building joints of the state and the state government system. From both these terms can be said that the Constitution contains the rules of the principal (fundamental) of the joints needed for the establishment of a state. ECS Wade says that is the purpose of the Constitution is "a document having a special legal sanctity the which sets out the framework and the principle function the organs of government of a state and declares the principles governing the operation of Reviews those organs" which is interpreted as a script describes the framework and basic tasks of government agencies that have a country and determine the basic workings of the agency. If the state in view as authority or organization of power, the constitution can be viewed as a body or a collection of principles that define how power is divided among several institutions of state, such as between the legislature, executive, and judicial. The constitution establishes the ways in which these power centers work together and adapt to each other, record the relationship of power relations within a country.

In Latin, the word constitution is a combination of two words, namely Cume and statuere. Cume is a preposition meaning "together with ...," while statuere standing have meaning. From this basis word Statuere Cume has the meaning "to make something to stand or set up / set." Thus the singular form of the constitution is to establish something together and the plural form of the constitution is all that is in charge.

The Constitution can be interpreted in a broad sense and narrow, as follows:

a. The Constitution (basic law) in a broad sense includes basic laws and unwritten.

b. The Constitution (basic law) in the narrow sense is the basic law says that constitution. In this sense constitution is the constitution or basic law is written. (Winarno, 2008).

\section{b. The Nature and Function of the Constitution}

in essence a strict constitution must contain materials that should substantially exist on a constitution. According to Miriam Budiharjo, every constitution contains provisions regarding the following matters:

1) organization of the State, such as the division of powers between the legislature, executive, and judicial branches of government, the division of powers between the federal government and state government, the procedure to solve the problem violation jurisdiction by one of the government agencies and so on.

2) Human rights.

3) The procedure to change the Constitution.

4) There are times when load restrictions to alter certain properties of the Basic Law. (Nuruddin Hady, 2010)

Constitution occupies a very important position in the constitutional life of a Contracting State from the constitution a barometer of people and the nation laden with historical evidence of struggle predecessors. Although the existing constitution of the world vary both in terms of objectives, form and content, but generally they have accrued the same formal, namely as:

1) the Constitution as the basic law, since it contains the rules and regulations on matters fundamental to life a country.

2) Constitution as the supreme law, meaning that the rules contained in the constitution, in the hierarchy has a notch higher against other rules, so that other rules should be in accordance with the Basic Law. 
3) According Jimly Asshiddiqie in Winarno 2008 constitution has the following functions:

a) Function determinant or limiting the power of the State.

b) Regulatory function of power relations inter organs State.

c) Regulatory function power relations between organs by citizens.

d) Function giver or the source of the legitimacy of state power or activities of the organization of state power.

e) Functions distributor or transferor authority of the original power source (in a democracy is the people) to the organs of the State.

f) The symbolic function, namely as a means of unifying(symbolofunity), as a reference to the identity and nationality of grandeur(identityof the nation) as well as the center of ceremonies.

g) Function as a means of controlling society (social control), both in the narrow sense that the political field and in a broader sense includes the socio-economic field.

h) Function as a means of engineering and public updates. (Winarno, 2008)

\section{c. History of Birth 1945 As the Constitution of the Country Indonesia}

Constitution plays an important role for the life of a country, as evidenced by the fact the history of the Homeland itself, when the Japanese Military Administration promised to give independence to the people of Indonesia through the Prime Minister Koiso spoken on September 7, 1944, then formed entity named Dokuritsu Zyunbi Choosakai (Investigation Agency efforts Preparation of Indonesian Independence / BPUPKI) on 29 Arpil 1945, chaired by Dr. Radjiman Wedyodiningrat and Deputy Chief RP Soeroso, whose job preparing the Basic Indonesia Merdeka (Constitution).

The members BPUPKI were inaugurated on May 28, 1945 convened in two phases: first, from May 29th - June 1st, 1945 to establish the basis of state and succeeded in formulating Pancasila which is based on a speech by members of Soekarno on June 1, 1945, the second, from the 10th - July 17th, 1945 that managed to make the Constitution. At the end of the first trial, the chairman of the session to form a committee consisting of eight members led by Ir. Sukarno, called the Committee of Eight. On June 22, 1945 meeting between the combined understand national and religious groups who questioned the relationship between religion and state. In the meeting, Committee for nine, consisting of Drs. Moh. Hatta, Mr. A. Subardjo, Mr. AA Maramis, Ir. Sukarno, KH. Abdul Kahar Moezakir, Wachid Hasyim, Abikusno Tjokrosujoso, H. Agus Salim and Mr. Muh. Yamin. Nine committee managed to draft Preamble Basic Law, which Mr. Muh. Yamin called the Charter Jakarta (Jakarta Charter).

On July 14, 1945 in the second trial BPUPKI, after debate and change, the text of Statement of Indonesia Merdeka and the text accepted by the 1945 opening of the trial. Text Statement of Indonesia Merdeka and the 1945 opening text is the work of designer Constitution Committee, chaired by Prof. Supomo. After completion of his duties, BPUPKI report the results to the Japanese Military Administration with the proposed establishment of a new entity that is Dokutsu Zyunbi Linkai (Committee for Indonesian Independence / PPKI), which is responsible for managing the transfer of power (transfer of authority) of the Government of Japan to the Government of Indonesia. The proposal will be established PPKI with a membership of 21 people, headed by Ir. Soekarno and Vice-Chairman Drs. Moh. Hatta. PPKI then added 6 people. but smaller than the number of member BPUPKI, ie 69 people. 
According to the plan, Japan would give independence to the people of Indonesia on August 24,1945 . But there is a hidden God's grace (blessing in disguise) because, ten days before the arrival of the D-Day, Japan declared unconditional capitulation to the Allies unconditional surrender).

In the three days that determines, on the 14th, 15th, and August 16, 1945 ahead of the Independence Day, the 14th, 15th, and August 16, 1945 ahead of Independence Day, a conflict between Soekarno-Hatta with youth groups in the decision problem, ie concerning how and when it will be announced independence. Soekarno-Hatta still want to first consult with the Government of Japan, while the youth group wanted to be independent and completely free from the intervention of the Government of Japan.

On Thursday morning, 16 August 1945, Soekarno-Hatta taken (abducted) by the youth to Rengasdengklok, but in the evening brought back to Jakarta and then held a meeting in the house of Admiral Maeda at Jalan Imam Bonjol No. 1 Jakarta. On that night reached an agreement that will be announced in the Declaration of Independence Road East Pegangsaan 56, which is the residence of Bung Karno, on Friday, August 17th, 1945 (9 Ramadhan 1364), at 10:00 am.

On August 17, 1945 afternoon came envoys from Eastern Indonesia are facing Drs. Moh. Hatta and stated that the people in the area objected to the part of the sentence in the design of the 1945 Constitution which reads: "deity, with the obligation to enforce Sharia Law for adherents". In the face of these problems, accompanied by the spirit of unity, the next day before the trial PPKI August 18, 1945, can be completed by Drs. Moh. Hatta joint 4 PPKI, namely KH Wachid Hasyim, Ki Bagus Hadikusumo, Mr. Kasman Singodimedjo and Teuku M. Hasan. Thus the seven words of the preamble of the 1945 Constitution eliminated. For more details can be explained that the agency that designed the 1945 Constitution includes basic design BPUPKI Pancasila state is established on April 29, 1945. After completion of his duties following is designing the 1945 draft state basis, and a draft statement of Indonesia's independence, then formed PPKI on August 7, 1945. So the constitution of Indonesia is Act of 1945, which was first approved by the Committee for Indonesian Independence (PPKI) on August 18, 1945.

\section{d. The dynamics of implementation of the State Constitution 1945 As Indonesia}

Historically, since the proclamation of August 171945 until now in Indonesia has been true three kinds of constitution into four periods, namely:

1) period of August 18,1945-December 27194919451945 Constitution applies consists of the opening, the trunk (16 chapters), 37 articles, 4 article Transitional rules, paragraph 2 Additional rules and part explanation.

2) The period of December 27, 1949 - August 17, 1950 apply the Constitution RIS. RIS Constitution consists of 6 chapters, 197 chapters and sections.

3) The period of August 17, 1950 - July 5, 1959 apply the 1950 Provisional Constitution consists of 6 chapters, 146 chapters and sections.

4) The period of July 5, 1959 - now back in force of the 1945 Constitution applies Especially for the fourth period 1945 to the following divisions:

1) 1945 which has not diamandeme

2) 1945 as amended $(1999,2000,2001$, and 2002). (Winarno 2008) 


\section{3) 1945 Effective August 18, 1945 until December 27, 1949}

In the period in the implementation of the Constitution can not be implemented properly, because the Indonesian nation is in the transition period, meaning that in future efforts to defend and maintain the independence was proclaimed. While the party still wants colonize back colonial Indonesian state.

The constitution in force from August 18, 1945 until December 27, 1949 contains provisions constitution Indonesian government system is presidential. That is, the ministers are not accountable to the legislature, but only act as assistant to the president. Furthermore, starting in November 1945, in virtue of Vice President No. X dated October 16, 1945, announcement Agency Workers 11 November 1945, and the edicts Government on 14 November 1945, the political responsibility lies in the hands of the minister. This situation is the beginning of a parliamentary system of government that is practically maintained until 1959 , through the decree of the President. So, starting on November 141945 to 27, December 1949, held different governmental system with a system of government as stipulated in the text of the Constitution of 1945 (Miriam Budihardjo 2007 in Sunarso et al, 2008).

1) Applicable RIS Constitution December 27, 1949 until August 17, 1950

Then the constitution in force from December 27, 1945-August 17, 1950 was the constitution of RIS. With the establishment of the Republic of Indonesia (RIS), the Republic of Indonesia (RI) is legally remain just changed its status to one of the states of the country RIS. Act of 1945, which was originally valid for the entire territory of Indonesia, from December 27, 1949 is valid only within the territory of the State of the Republic of Indonesia alone.

RIS state with its constitution is very short because it does not conform with the spirit of the declaration of independence who wanted a unitary state, so that some states began to merge again with the Republic of Indonesia.

RIS Constitution this can not happen in quite a long time, but only approximately 8 months (27desember 1949 to 17 August 1950). This occurs because of the demands of people from different areas to get back to form a unitary state and leaving the country form RIS. This fact makes the state RIS disbanded and rejoined from unified state with its capital in Yogyakarta. In 1950, the state ris that have not joined the Homeland is the state of eastern Indonesia and the state of eastern Sumatra, but in a short time reached between the Homeland with both states. With the deal, then on 17 August 1950 RIS country officially re-joined the Homeland.

\section{2) Provisional Constitution of August 17, 19501950 Valid until July 5th 1959}

Constitution while in 1950 this is the third for the Indonesian Constitution. According to this UUDS system of government, adopted is a parliamentary system of government and not a presidential system of government more like the Constitution 45. According to the parliamentary system of government as stipulated in the Provisional Constitution, the president and the vice president is the head of government and can not be disturbed accountable for responsible is the ministers to the parliament (DPR). Provisional Constitution, is grounded in liberal thinking that prioritizes individual constitution, while 1945 rests on a foundation of Pancasila democracy containing the fourth principle.

In the implementation of the system parliamentary taken by this UUDS cause of not achieving political stability and the government, because of frequent alternation of the cabinet which is based on the support of a voice in parliament. During 1950 and 1959 a change of cabinet for 7 times, implying that many cabinet program that does not run and is not sustainable. Besides 
hearing the constituent assembly is the result of democratic elections in september and december 1955, was tasked to draft a new constitution instead of 1945 as a form of accommodation of the aspirations of the people who wanted a change from the Provisional Constitution to the new constitution that is experiencing congestion (stagnant) during 2 years. Given the impact of the stagnant discussion Ruud, in a relatively long time has raised concerns that the constituent assembly will fail to finish. Such political condition made the government (of President Soekarno) issued a presidential decree on 5 July 1959 the contents of which we return to the 1945 Constitution

\section{3) 1945 Valid Until 1966 July 5, 1959}

Which is a unitary state constitutional changes of the union state using the Constitution Whilst 1950 in his opening load Pancasila state ideology, but the implementation of the system of government using a parliamentary cabinet system. Thus, the parliamentary cabinet system is incompatible with the spirit of Pancasila (Sunarso, 2008).

Implementation of the 1945 Constitution at this time or which is known as the New Order in the leadership of President Suharto can be noted regarding the implementation of the constitution, namely:

a. Establishing institutions in the 1945 Constitution stipulated in the law.

b. Holding a five-year national leadership mechanism of carrying out the Parliament elections, the election of president and vice president, lift cabinet, accountability report in the general assembly of the Assembly and so on.

c. Using a presidential system of government as stipulated in the 1945 Constitution.

d. 1945Amendment, 1999, prevailing in the year 1999 until now

In the implementation of the constitution amendment of the 1945 Constitution, the system of government's changed significantly with the implementation of the constitutional system of government in 1945 pre amendment.

At the time of this reform, the 1945 undergoing a process of amendment after the expiration of the constitutional government of President Soeharto. In application of the amendment of the 1945 Constitution, the system of government's changed significantly with the implementation of the constitutional system of government in 1945pre amendment.

\section{Amendment of the Constitution 1945(1999-2002)}

Amendment (English: the amendment) means change. Amend means to change or amend in which the rights of parliament to amend or propose changes to the draft constitution. According to (Taufiqurohman Syahuri 2004 in Winarno 2007) term change in the constitution itself includes two meanings, namely amending the constitution(constitutional amendment )and reform the constitution(constitutional reform). In the case of constitutional amendments, changes were made to the addendum or insertion of the original constitution. Between the changes in the original constitution is still relevant. Old values in the original constitution is still there. This changes the system adopted by the United States.

In terms of constitutional reform, the changes made are the "new" overall. So prevailing is old or original constitution. This system adopted by countries such as the Netherlands, Germany, and France.

Connection with the question why the need for the 1945 amendments is because human life is constantly changing, both internal changes in society, such as thoughts, needs, abilities and 
external life of the community, such as environmental change and relations with other society. Therefore, the constitution as the foundation of life of the state must constantly adjust to developments and demands in society.

Soeharto considered to have been shackled aspirations of the people and reduce the role of political institutions. Political parties do not play a role, Parliament is weak in front of the executive and therefore becomes unbalanced distribution of power between the executive, legislative, and judicial branches. President enormous power and protection of human rights is severely limited and the mechanism of checks and balances are inadequate. Therefore, the pressure to amend the 1945 Constitution was getting stronger. Although there are pros and cons, but the 1945 amendments remain to be done, but with the agreement that the opening section of the 1945 Constitution should not be changed while maintaining the Unitary Republic of Indonesia and the presidential system of government, the explanation of the 1945 Constitution abolished and things normative in part the explanation was appointed to the chapters. Changes made by way of 'addendum' of each new chapter of the amendment will always be accompanied by the original article. The goal is that the historical context can be preserved so that they can continue to be studied by future generations (Nuruddin Hady, 2010).

Overall the 1945 amendment that basically include provisions concerning (a) the rights of human rights, the rights and obligations of citizens, as well as mechanisms to the state and the procedures to maintain it when those rights are violated, (b) the basic principles of democracy and the rule of law as well as the realization and implementation mechanisms, such as through elections, and others, and (c) the format of state institutions and the mechanisms of the relationship between state organs and systems of accountability officials.

In other words, according to (Jimly Assidiqie 2007 in Sunarso et al, 2008), those mentioned in the first amendment to the fourth amendment of the 1945 Constitution includes all of the subject matter all the basic laws of modern countries in the world.

It can not be denied that the 1945 changes this brings progress. It is obvious that democracy grows better life. 1945 of the amendment already bring up provisions on cheks and balances are more proportionate in the state system of Indonesia. Prior to the 1945 amendment, many products legislation contrary to the laws and regulations are higher, as many laws that are contrary to the 1945 Constitution, but no testing agencies that could be operationalist. Now we can see the progress made by the presence of Court's role in the Act, as the implementation of checks and balances that is good for the constitutional system. Now the legislature can no longer make laws with recklessly or through certain political transactions, because the legislation now can be monitored and offset by a judicial body, the Constitutional Court (Moh. Mahfud MD, 2010).

With the 1945 amendment, the Assembly institution undergoes a transformation notch from the highest state institutions into state institutions. MPR power has been poor. MPR no longer authorized to elect the president and vice president's spouse, but it is the people that are now sovereign to choose a pair of President and Vice President. In other words, sovereignty belongs to the people. Which before was amended highest power in the hands of the Assembly. The division of power is also set out clearly among the executive, legislative, and judicial branches. The executive power is delegated to the president, delegated legislative power to the president, DPR and DPD, and power judicial delegated to the Supreme Court. While the function of control or power inspective, delegated to the Audit Board (BPK) and the House of Representatives. After the amendment, there is no consultative powers, which before was 
amended delegated to the Supreme Advisory Council. In the judicial authorities there are 2 new institution after being amended, namely the Judicial Commission and the Constitutional Court.

\section{CONCLUSION}

Based on the above discussion it can be concluded as follows:

a. The Constitution is the constitutional system in the form of written and unwritten rules set out together to govern a country. Where the nature and function of the constitution is there limitation of government power so that the implementation of power is not arbitrary. Thus, the rights of citizens are expected to be protected. 1945 was passed by the state constitution PPKI as Indonesia on August 18, 1945. In practice, the 1945 Constitution of Indonesia has been transformed into constitutional RIS (December 27th 1945-August 17, 1950), later transformed into a Provisional Constitution of 1950 (August 17th 1950s July 5th, 1959), until it became 1945 again but with amendments in 1999, 2000, 2001 and 2002.

b. An amendment to the 1945 Constitution because their demands strong 1945 changes of society. People feel that the charge 1945 times many are not appropriate.

\section{REFERENCES}

Abdul Ghoffar, 2009, Perbandingan Kekuasaan Presiden Indonesia Setelah Perubahan UUD 1945 dengan delapan negara maju, Cetakan 1, Kencana, Jakarta.

AV Dicey , 2015, Pengantar Studi Hukum Konstitusi, Nusamedia, Bandung.

Bagir Manan, Susi Dwi Harjanti, 2015, Memahami Konstitusi Makna Dan Aktualisasi, PT.Raja Grafindo Persada, Cetakan II, Jakarta.

CF Strong, 2015, Studi Perbandingan tentang Sejarah dan Bentuk, Nusamedia, Bandung.

Hady, Nuruddin. 2010. Teori Konstitusi dan Negara Demokrasi. Malang, Setara Press.

KC Wheare, 2006, Konstitusi Konstitusi Moderen Modern Constitutions, Nusamedia, Bandung

Mahfud MD, Moh. 2010. Perdebatan Hukum Tata Negara. Jakarta : Rajawali Pers.

Margarito Kamis, 2014, Jalan Panjang Konstitusionalisme Indonesia, Setara Press, Malang.

Srijanti dkk. 2008. Etika Berwarga Negara. Jakarta, Salemba Empat.

Sunarso dkk. 2008. Pendidikan Kewarganegaraan Untuk Perguruan Tinggi, Yogyakarta, UNY Press.

Winarno. 2008. Paradigma Baru Pendidikan Kewarganegaraan. Jakarta, Bumi Aksara. 